\title{
In Vitro Antibacterial and Antibiofilm Activity of Lippia alba Essential Oil, Citral, and Carvone against Staphylococcus aureus
}

\author{
Emanuela Mesquita Porfírio, ${ }^{1}$ Hider Machado Melo, ${ }^{1}$ \\ Antônio Matheus Gomes Pereira, ${ }^{1}$ Theodora Thays Arruda Cavalcante, ${ }^{1}$ \\ Geovany Amorim Gomes, ${ }^{2}$ Mário Geraldo de Carvalho, ${ }^{3}$ \\ Renata Albuquerque Costa, ${ }^{1}$ and Francisco Eduardo Aragão Catunda Júnior ${ }^{1,4}$ \\ ${ }^{1}$ INTA College, Cel. Antonio Rodrigues Magalhães, 359 Sobral, CE, Brazil \\ ${ }^{2}$ State University of Acaraú Valley, 62040-370 Sobral, CE, Brazil \\ ${ }^{3}$ Federal Rural University of Rio de Janeiro, 23890-000 Seropédica, RJ, Brazil \\ ${ }^{4}$ State University of the Tocantina Region of Maranhão, 65901-480 Imperatriz, MA, Brazil
}

Correspondence should be addressed to Renata Albuquerque Costa; renata.albuq@gmail.com

Received 22 February 2017; Accepted 21 June 2017; Published 3 August 2017

Academic Editor: Carin von Muhlen

Copyright (C) 2017 Emanuela Mesquita Porfírio et al. This is an open access article distributed under the Creative Commons Attribution License, which permits unrestricted use, distribution, and reproduction in any medium, provided the original work is properly cited.

\begin{abstract}
In vitro antimicrobial and antibiofilm activities of the Lippia alba essential oil and its major components (citral and carvone) against Staphylococcus aureus were investigated. Essential oils (LA1EO, LA2EO, and LA3EO) were extracted from the aerial parts of three L. alba specimens by hydrodistillation and analyzed by gas chromatography coupled to a mass spectrometer. Minimum Inhibitory Concentrations (MIC) and Minimum Bacterial Concentration (MBC) were determined by the microdilution method. For the antibiofilm assays, the biomass formation in the biofilm was evaluated by the microtiter-plate technique with the crystal violet (CV) assay and the viability of the bacterial cells was analyzed. All oils and their major components presented antibacterial activity, and the lowest MIC and MBC values were $0.5 \mathrm{mg} \mathrm{mL}^{-1}$ when LA1EO and citral were used. Potential inhibition (100\%) of S. aureus biofilm formation at the concentration of $0.5 \mathrm{mg} \mathrm{mL}^{-1}$ of all EOs was observed. However, the elimination of biofilm cells was confirmed at concentrations of $1 \mathrm{mg} \mathrm{mL}^{-1}, 2 \mathrm{mg} \mathrm{mL}^{-1}, 2 \mathrm{mg} \mathrm{mL}^{-1}$, and $0.5 \mathrm{mg} \mathrm{mL}^{-1}$ for LA1EO, LA2EO, LA3EO, and citral, respectively. The results obtained in the present research point to the promising antibacterial and antibiofilm potential of $L$. alba EOs against $S$. aureus, a species of recognized clinical interest.
\end{abstract}

\section{Introduction}

Antimicrobial resistance in bacterial pathogens is a public health problem worldwide and is associated with high morbidity and mortality, jeopardizing the efficacy of antibiotics. In this sense, $S$. aureus, a Gram-positive bacterium recognized as a pathogenic agent, is associated with food poisoning $[1,2]$ and/or severe infection [3]. In this study, the use of resistant strains to methicillin [4] and vancomycin [5] has been highlighted.

This problem of bacterial resistance has been attributed to the excessive and incorrect use of drugs, as well as the lack of development of new drugs by the pharmaceutical industry, thus arising from the need to search for natural products that may come to combat these "superresistant bacteria" [6-9].

Natural products extracted from plants are identified as an alternative for the discovery of new active antimicrobial agents through empirical knowledge regarding the use of medicinal plants [10]. The use of antimicrobial phytotherapeutics is considered as a possible source of new antibiotic discoveries with a broad spectrum of actions different from traditional antibiotics [11].

Among the plants recognized for their pharmacological action are those belonging to the genus Lippia, which comprises about 200 species distributed in tropical, subtropical, and temperate regions of America, Africa, and Asia [12]. The 
species L. alba is a shrub of the Verbenaceae family, popularly known as lemon balm. Its essential oil is mentioned with a broad spectrum of activities against Gram-negative and Gram-positive bacteria, whose effectiveness varies according to its composition, which is influenced by biotic and abiotic factors [13].

Thus, the present study aims to evaluate the antibacterial and antibiofilm activity of essential oils of three $L$. alba chemotypes and of their major compounds (citral and carvone) against $S$. aureus.

\section{Materials and Methods}

2.1. Plant Material. Aerial parts of three chemotypes of $L$. alba were collected. The first was collected in July 2014, and the second was collected in June 2016, both at the Experimental Farm of the INTA College, located in the municipality of Cariré, northwest of Ceará state, Brazil, at $3^{\circ} 49^{\prime} 5182^{\prime \prime} \mathrm{S} 40^{\circ} 24^{\prime} 3785^{\prime \prime} \mathrm{W}$, at 76 meters from sea level, and the third one was collected in March 2016, in the Medicinal Plants Garden of Sumaré in the municipality of Sobral, northwest of Ceará state, Brazil, at $3042^{\prime} 0731^{\prime \prime} \mathrm{S} 40021^{\prime} 53$ $66^{\prime \prime} \mathrm{O}$, at 88 meters from sea level. The voucher specimens (numbers 17481, 20790, and 20441) were deposited in Prof. Francisco José de Abreu Matos Herbarium (HUVA) of the Center for Agricultural Sciences and Biological Sciences, State University of Acaraú Valley, Sobral, Ceará state, Brazil.

2.2. Extraction of Essential Oils. Aerial parts were air-dried, ground, and submitted to hydrodistillation $(\sim 1 \mathrm{~kg}, 3 \mathrm{~h})$ using a Clevenger-type apparatus for LAEO obtention. Oils were dried with anhydrous $\mathrm{Na}_{2} \mathrm{SO}_{4}$ and transferred to glass flasks that were kept at $-5^{\circ} \mathrm{C}$ until used. Yield of $0.578 \% \mathrm{w} / \mathrm{w}$, $1.203 \% \mathrm{w} / \mathrm{w}$, and $2.654 \% \mathrm{w} / \mathrm{w}$ was observed for LA1EO, LA2EO, and LA3EO, respectively.

2.3. Analysis of the Essential Oil. The chemical composition of the essential oil was analyzed according to Figueiredo et al. [14]. A gas chromatograph coupled to a mass spectrometer (GC/MS, Shimadzu QP-2010 Plus) equipped with a Factor Four/VF (5 ms) fused-silica capillary column $(30 \mathrm{~m}$ $\times 0.25 \mathrm{~mm} \times 0.25 \mu \mathrm{m}$ film thickness), with helium as carrier gas at $1 \mathrm{~mL} \mathrm{~min}^{-1}$, was used. The initial oven temperature was $35^{\circ} \mathrm{C}$, which after being held constant for 2 min was increased at a rate of $4^{\circ} \mathrm{C} \mathrm{min}^{-1}$ to $180^{\circ} \mathrm{C}$, followed by $10^{\circ} \mathrm{C} \mathrm{min}^{-1}$ to $250^{\circ} \mathrm{C}$, with a final isotherm $\left(250^{\circ} \mathrm{C}\right)$ for $20 \mathrm{~min}$. The sample injection was $1 \mu$ (1:50 split mode). The injector and detector temperatures were both $250^{\circ} \mathrm{C}$. The mass spectra were obtained in a range of $\mathrm{m} / z 10-300$, by the electron impact technique at $70 \mathrm{eV}$. The quantitative analysis of the oils' chemical composition was carried out in a gas chromatograph coupled to an HP5890 Series II flame ionization detector (FID), using the same operational conditions and the same type of column as in the GC/MS analysis, with the exception of the injector and detector temperatures that were 240 and $300^{\circ} \mathrm{C}$, respectively. The percentage of each constituent was calculated by the integral area under the respective peaks in relation to the total area of all the sample constituents. The various chemical constituents of the essential oil were identified by visual comparison of their mass spectra with those in the literature [15] and spectra supplied by the equipment database (NIST 08), as well as by comparison of the retention indices with those in the literature [15]. A standard solution of $n$-alkanes (C8-C20) was injected under the same chromatographic conditions as the sample and used to obtain the retention indices as described by van Den Dool and Kratz [16].

2.4. Solutions and Drugs. Citral and carvone (Sigma-Aldrich, USA) were used to perform the microbiological tests.

2.5. Strain Origin. Staphylococcus aureus ATCC 6538 was used. This strain was stored in Skin Milk with 20\% glycerol and was reactivated in Tryptone Soy Broth for bacteriological analyses.

2.6. Minimum Inhibitory Concentration (MIC). MIC was determined by microdilution assay on 96-well polystyrene plates [17] with 20 replicates. To perform the test, the bacterial culture concentration was adjusted to $10^{6}-10^{8} \mathrm{CFU} \mathrm{mL}^{-1}$ in Tryptic Soy Broth medium (Difco). The test substances (LA1EO, LA2EO, LA3EO, citral, and carvone) were tested at the concentrations of $4,2,1,0.5,0.25,0.125$, and $0.062 \mathrm{mg}$ $\mathrm{mL}^{-1} .100 \mu \mathrm{L}$ of the adjusted culture was placed in contact with the test substances and the plates were incubated in an oven at $37^{\circ} \mathrm{C}$ for $24 \mathrm{~h}$. MIC was considered the lowest concentration of the test substance where no microbial growth was visualized.

2.7. Minimum Bactericidal Concentration (MBC). MBC was determined by the plating of $10 \mu \mathrm{L}$ (in triplicate) of the well contents of the plates used in the MIC (after the incubation period) in Tryptone Soy Agar (Difco). CBM was considered the lowest concentration of the test substance in which no microbial growth was observed after the incubation period $\left(37^{\circ} \mathrm{C}\right.$ for $\left.24 \mathrm{~h}\right)$.

2.8. Antibiofilm Activity. The biofilm biomass formation was evaluated using the microtiter-plate technique with the crystal violet (CV) assay [18], and the viability of the bacterial cells in the biofilm was analyzed [19]. The biofilms associated with the surface of the wells were fixed with methyl alcohol and stained with $0.1 \%$ crystal violet for fifteen minutes. After this period, each plate was washed (TriContinent's MultiWash III) and subjected to absorbance reading in a microplate reader (SpectraMax) at $595 \mathrm{~nm}$. In order to verify the viability of the bacterial cells in the biofilm $\left(10^{-1}\right.$ to $\left.10^{-6}\right)$, the plates were submitted to an ultrasonic bath (GNATUS Digital Ultrasonic Cleaner) for 5 minutes, which were plated (10 $\mu \mathrm{L}$ in triplicate) on Tryptic Agar Soy (Difco), and were incubated at $37^{\circ} \mathrm{C}$ for $24 \mathrm{~h}$. After the incubation period, colony forming units (CFU $\mathrm{mL}^{-1}$ ) were determined.

2.9. Controls. For the CIM, CBM, and antibiofilm activity, we used as turbidity control the culture medium (TSB) 
TABLE 1: Chemical composition, calculated retention index $\left(\mathrm{RI}_{C}\right)$, percentages of identified components (\%), and similarity index (SI) in comparison with MS library, of essential oils from Lippia alba chemotypes: LA1, LA2, and LA3.

\begin{tabular}{|c|c|c|c|c|c|c|c|}
\hline Component & $\mathrm{RI}_{\mathrm{C}}$ & LA1 & SI & LA2 & SI & LA3 & SI \\
\hline Sabinene & 975 & 0.54 & 93 & $-^{a}$ & - & - & - \\
\hline 6-Methyl-5-hepten-2-one & 985 & 3.89 & 96 & 2.34 & 94 & - & - \\
\hline Myrcene & 990 & 4.08 & 96 & - & - & - & - \\
\hline p-Cymene & 1024 & 9.84 & 95 & 4.12 & 96 & 0.96 & 91 \\
\hline Limonene & 1029 & - & - & 1.64 & 95 & 5.25 & 94 \\
\hline$\gamma$-Terpinene & 1059 & 0.41 & 95 & - & - & 1.70 & 93 \\
\hline E-4-Thujanol & 1070 & 0.58 & 94 & 1.23 & 90 & - & - \\
\hline Z-Linalool oxide & 1072 & - & - & 0.13 & 91 & - & - \\
\hline$E$-Linalool oxide & 1086 & - & - & 0.27 & 92 & - & - \\
\hline Linalool & 1096 & 1.16 & 96 & 1.02 & 94 & 1.38 & 91 \\
\hline Z-Limonene oxide & 1136 & - & - & 0.75 & 88 & - & - \\
\hline E-Limonene oxide & 1142 & - & - & 1.12 & 89 & - & - \\
\hline$E$-Isocitral & 1180 & 0.39 & 96 & - & - & - & - \\
\hline Citronellol & 1225 & - & - & 2.30 & 85 & - & - \\
\hline Nerol & 1229 & 1.64 & 95 & - & - & - & - \\
\hline Neral & 1238 & 26.44 & 97 & 18.42 & 96 & 2.88 & 95 \\
\hline Carvone & 1243 & - & - & 4.25 & 94 & 71.54 & 97 \\
\hline Piperitone & 1252 & - & - & - & - & 0.73 & 90 \\
\hline Geraniol & 1252 & 1.86 & 96 & - & - & - & - \\
\hline Geranial & 1267 & 35.82 & 97 & 24.87 & 97 & 4.66 & 95 \\
\hline Hydroxycitronellal & 1288 & - & - & 2.73 & 76 & - & - \\
\hline Neric acid & 1340 & 0.42 & 92 & 5.19 & 84 & - & - \\
\hline Geranic acid & 1359 & 0.36 & 96 & 17.24 & 95 & - & - \\
\hline Germacrene D & 1485 & - & - & - & - & 2.51 & 92 \\
\hline Cubebol & 1515 & - & - & - & - & 0.92 & 73 \\
\hline Elemol & 1549 & 5.41 & 95 & 5.04 & 94 & 3.90 & 93 \\
\hline Germacrene D-4-ol & 1575 & - & - & - & - & 0.88 & 72 \\
\hline Caryophyllene oxide & 1583 & 0.95 & 92 & - & - & - & - \\
\hline Guaiol & 1600 & 1.49 & 91 & - & - & 0.92 & 87 \\
\hline$($ Citral $=$ neral + geranial $)$ & & $(62.26)$ & - & $(43.29)$ & - & $(7.54)$ & - \\
\hline Total & & 95.28 & - & 92.64 & - & 98.23 & - \\
\hline
\end{tabular}

${ }^{\mathrm{a}}$ Not detected.

containing the test substance (LA1EO, LA2EO, LA3EO, citral, and carvone) at concentrations of $4 \mathrm{mg} \mathrm{mL}^{-1}, 2 \mathrm{mg} \mathrm{mL}^{-1}$, $1 \mathrm{mg} \mathrm{mL}{ }^{-1}, 0.5 \mathrm{mg} \mathrm{mL}^{-1}, 0.25 \mathrm{mg} \mathrm{mL}^{-1}, 0.125 \mathrm{mg} \mathrm{mL}^{-1}$, and $0.0625 \mathrm{mg} \mathrm{mL}^{-1}$. For contamination control, only the culture medium (TSB) in three wells on the plates was used. The negative control was made from the inoculation of $100 \mu \mathrm{L}$ of strain $\left(1.25 \times 10^{7} \mathrm{CFU} \mathrm{mL} \mathrm{m}^{-1}\right)$ in wells containing culture medium (TSB). As a positive control, vancomycin was used in the same concentrations of the test substances: $4 \mathrm{mg} \mathrm{mL}^{-1}$, $2 \mathrm{mg} \mathrm{mL}^{-1}, 1 \mathrm{mg} \mathrm{mL}^{-1}, 0.5 \mathrm{mg} \mathrm{mL}^{-1}, 0.25 \mathrm{mg} \mathrm{mL}^{-1}, 0.125 \mathrm{mg}$ $\mathrm{mL}^{-1}$, and $0.0625 \mathrm{mg} \mathrm{mL}^{-1}$.

2.10. Statistical Analysis. ANOVA (analysis of variance) was used followed by the Student-Newman-Keuls test with 95\% confidence interval $(p<0.05)$.

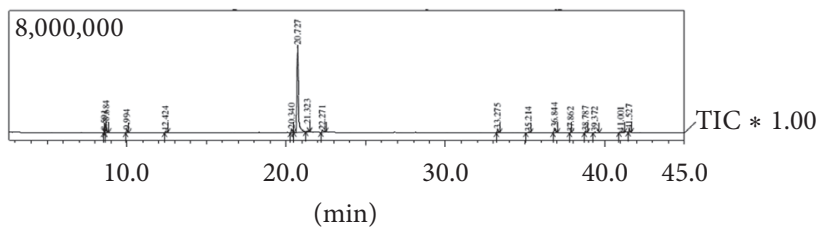

FIGURE 1: GC-MS chromatogram of the essential oil of Lippia alba: LA3 chemotype.

\section{Results and Discussion}

The results of the LA1EO, LA2EO, and LA3EO analyses are described in Table 1 and Figure 1. The chemical constituents that obtained concentrations above $10 \%$ were considered 
TABLE 2: Minimum Inhibitory Concentration (MIC) and Minimum Bactericidal Concentration (MBC) of Lippia alba essentials oils (LA1EO, LA2EO, and LA3EO), citral, and carvone against Staphylococcus aureus.

\begin{tabular}{lcc}
\hline Substance & MIC $\left(\mathrm{mg} \mathrm{mL}^{-1}\right)$ & $\mathrm{MBC}\left(\mathrm{mg} \mathrm{mL}^{-1}\right)$ \\
\hline LA1EO & 0.5 & 0.5 \\
LA2EO & 1.0 & 1.0 \\
LA3EO & 0.5 & 2 \\
Citral & 0.5 & 0.5 \\
Carvone & 2.0 & - \\
\hline
\end{tabular}

as the major constituents. For LA1EO, 25 components were identified, with predominance of geranial $(35.82 \%)$, neral $(26.44 \%)$, and $p$-cymene $(9.84 \%)$. LA2EO presented 23 identified components, with geranial (24.87\%), neral (18.42\%), and geranic acid (17.24\%) being the most prevalent. In LA3EO, 13 components were identified, with carvone (71.54\%) being the major one, followed by limonene $(5.25 \%)$ and geranial (4.66\%).

Due to the absence of established standardization for the differentiation of chemotypes in Lippia alba, many authors relied on the similarity between the major compounds present in the specimens of the species [20]. In the present study, the presence of these major compounds (citral and carvone) makes it possible to classify LAEO as three L. alba chemotypes.

According to Mamun-Or-Rashid et al. [12], at least 12 Lippia chemotypes have been described according to the major chemical components, namely, citral, linalool, carvone, limonene, $\gamma$-terpinene, citral-myrcene, citral-limonene, citral-caryophyllene, citral-germacrene $\mathrm{D}$, carvone-limonene, 1,8-cineole-camphor, 1,8-cineol-limonene, and limonenepiperitone, and there are predominantly monoterpene-like compounds such as citral, myrcene, and limonene.

The phytochemical analysis obtained for EOLA (Table 1) was similar to that reported by Machado et al. [13] that identified citral (31.6\%) and neral (25.5\%) as the main components of the LAOE. This indicates that the plant belongs to the "citral" chemotype composed of neral + geranial [21]. Similar values were also demonstrated in studies by Gonçalves et al. [22] (neral: 28.29\%; geranial: 38.88\%), and chemotype III (neral: 22.49\%; geranial: 34.64\%) and chemotype II (neral: 28.29\%; geranial: $38.88 \%$ ) were analyzed (carvone: $62.30 \%$; limonene: $16.31 \%)$.

The antimicrobial activity of the oils and their major components against $S$. aureus was confirmed by the values of MIC and MBC. The lowest MIC value $\left(0.5 \mathrm{mg} \mathrm{mL}^{-1}\right)$ was observed when LA1EO, LA3EO, and citral were used. For MBC, the lowest value was $0.5 \mathrm{mg} \mathrm{mL}^{-1}$ when LA1EO and citral were used (Table 2). Essential oils are hydrophobic compounds and easily diffuse through the cell wall of microorganisms, causing damage to the membrane, especially with respect to fluidity and permeability [23].

In this study, MIC and MBC values were the same for LA1EO and citral, both presenting bacteriostatic and bactericidal action at the concentration of $0.5 \mathrm{mg} \mathrm{mL}^{-1}$. LA2EO showed MIC and MBC at $1 \mathrm{mg} \mathrm{mL}^{-1}$ concentration ( $2 x$ higher concentration than LA1EO and citral). On the other hand, LA3EO showed an inhibitory action at the same concentration as LA1EO and citral. Carvone was able to reach inhibitory action only at the concentration of $2 \mathrm{mg} \mathrm{mL}^{-1}$, that is, at a concentration 4 times higher than that of the LA1EO, LA2EO, and citral oils. It can also be verified that the LA3EO presented bactericidal action only at the concentration of $2 \mathrm{mg} \mathrm{mL}^{-1}$ (concentration $4 \mathrm{x}$ greater than that of LA1EO and citral and $2 x$ greater than that of LA2EO). Our results show that the planktonic $S$. aureus ATCC 6538 has different susceptibility to EOs of L. alba and its major components, suggesting that the bacteriostatic and bactericidal actions are due to the synergistic action of the components of the oils and not only the action of the majority component.

The values obtained for CIM and CBM (Table 2) were lower than those reported by Sutili et al. [24] that demonstrated bacteriostatic and bactericidal action against $S$. aureus from the concentration of $2.8 \mathrm{mg} \mathrm{mL}^{-1}$ and $5.9 \mathrm{mg} \mathrm{mL}^{-1}$ LAEO, respectively. On the other hand, our results resemble those of Machado et al. [13] who presented MIC and MBC values at concentrations of $0.29 \mathrm{mg} \mathrm{mL}^{-1}$ and $0.33 \mathrm{mg} \mathrm{mL}^{-1}$, respectively, validating their antimicrobial potential.

All EOLA presented inhibition potential (100\%) of $S$. aureus (Figure 2) at the concentration of $0.5 \mathrm{mg} \mathrm{mL}^{-1}$ of LA1EO, LA2EO, citral, and carvone. In addition, potential inhibition was observed in the three concentrations below $0.5 \mathrm{mg} \mathrm{mL}^{-1}$ of LAEOs, citral, and carvone. The potential of biofilm formation of concentrations $0.25,0.125$, and $0.0625 \mathrm{mg} \mathrm{mL}^{-1}$ was lower than that observed in the positive control, vancomycin, which is the drug of choice for the treatment of infections caused by MRSA.

The antibiofilm activity of LAEOs should be highlighted, since this $S$. aureus is a successful human pathogen due to its metabolic versatility and its ability to adapt to host defensive stress [25]. This pathogen can cause mild infections and lifethreatening diseases, including skin and soft tissue infections, bacteremia, pneumonia, endocarditis, septicemia, and toxic shock syndrome [26].

Colony forming units count revealed that the elimination of biofilm cells was confirmed at concentrations of $1 \mathrm{mg} / \mathrm{mL}$, $2 \mathrm{mg} / \mathrm{mL}, 2 \mathrm{mg} / \mathrm{mL}$, and $0.5 \mathrm{mg} / \mathrm{mL}$ for LA1EO, LA2EO, LA3EO, and citral, respectively (Figure 3). No elimination of biofilm cells was observed when carvone was used (Figure 3).

In the present study, the antibiofilm action of OELA1 and OELA2 seems to be related to the presence of citral, since this isolated component presented the best results. Citral, a monoterpene (3,7-dimethyl-2,6-octadiene), is a combination of two neral and geranial isomers [27] and has a strong antimicrobial activity $[28,29]$.

The antibiofilm effect of LA3EO resulted from the synergistic action of its constituents and not only from the action of carvone, its major component, which was not able to completely eliminate the cells of the biofilm in formation. Carvone is a monoterpene found as the main active 

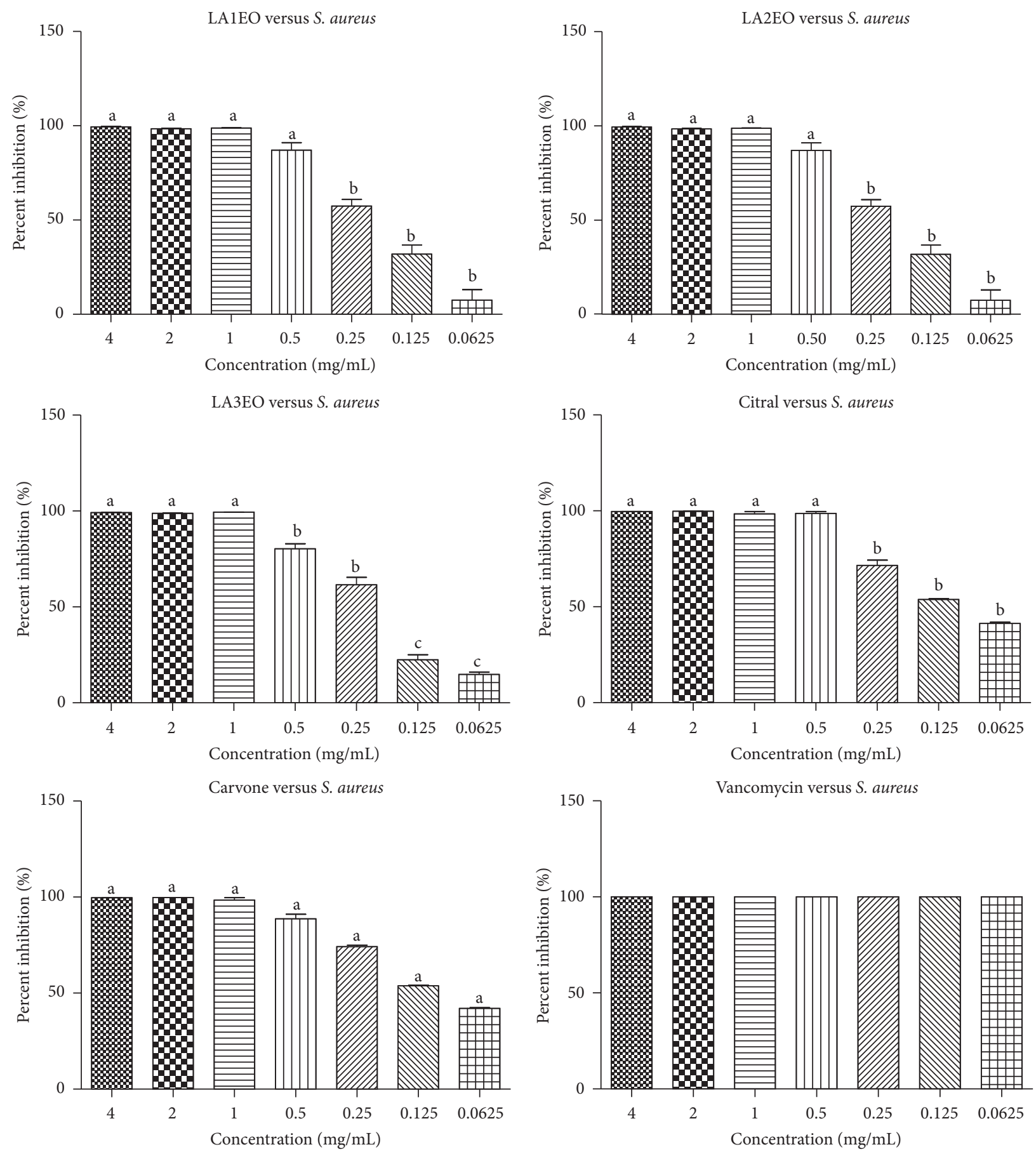

FIGURE 2: Inhibition (\%) of Staphylococcus aureus ATCC 6538 biofilm formation by essential oils of Lippia alba (LA1EO, LA2EO, and LA3EO), citral, carvone, and vancomycin in concentrations of $4,2,1,0.5,0.25,0.125$, and $0.062 \mathrm{mg} \mathrm{mL}^{-1}$. ANOVA followed by Student-Newman-Keuls test; $p<0.001$ (a) versus all variables; $p<0.001$ (b) versus (c).

component of several essential oils, such as mint (Mentha spicata L.), dill (Anethum graveolens L.), caraway (Carum carvi L.), and lemon grass (Lippia alba) [30]. Znini et al. [31] reported that carvone is one of the most effective antimicrobial agents of several plants, with a mechanism of antibacterial activity involving the destabilization of the structure of phospholipid and the interaction with membrane proteins, and acts as a proton exchanger reducing the $\mathrm{pH}$ gradient across the membrane [32].

Thus, our results point to the in vitro effect of the essential oils of three specimens of $L$. alba against planktonic and biofilm of S. aureus, a recognized pathogen of clinical interest. 


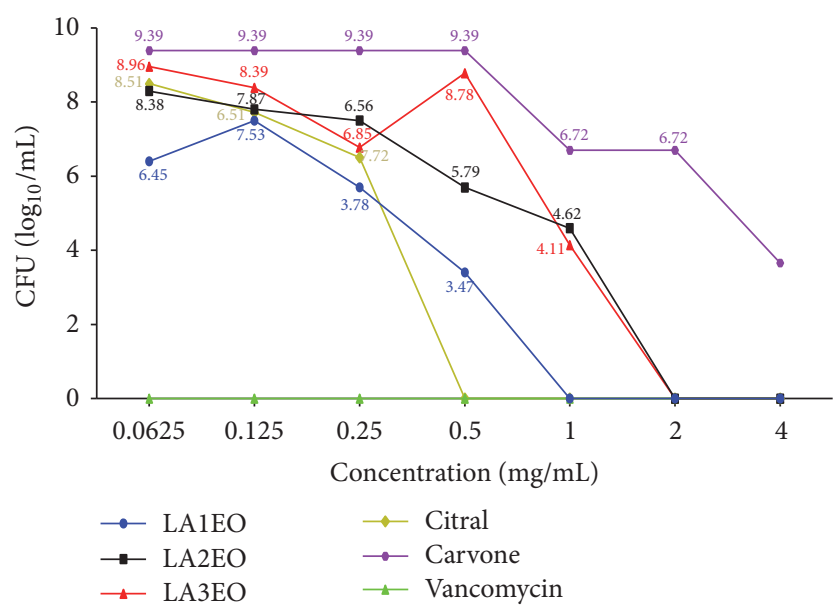

FIGURE 3: Colony forming units (CFU $\log _{10} \mathrm{~mL}^{-1}$ ) count of biofilm cells of Staphylococcus aureus ATCC 6538 after 24-hour treatment with essential oils of Lippia alba (LA1EO, LA2EO, and LA3EO), citral, carvone, and vancomycin at concentrations of $4,2,1,0.5,0.25$, 0.125 , and $0.062 \mathrm{mg} / \mathrm{mL}^{-1}$.

\section{Conflicts of Interest}

The authors declare that there are no conflicts of interest regarding the publication of this paper.

\section{References}

[1] S. M. Puah, K. H. Chua, and J. A. Mary Anne Tan, "Virulence factors and antibiotic susceptibility of Staphylococcus aureus isolates in ready-to-eat foods: Detection of S. aureus contamination and a high prevalence of virulence genes," International Journal of Environmental Research and Public Health, vol. 13, no. 2, article no. 199, 2016.

[2] N. A. Yunita, W. P. Rahayu, Suliantari, N. S. Nurjanah, and C. C. Nurwitri, "Identification and probability of illness of $S$. aureus contaminated food for school children," International Food Research Journal, vol. 23, no. 4, pp. 1767-1772, 2016.

[3] C. Kong, H.-M. Neoh, and S. Nathan, "Targeting Staphylococcus aureus toxins: A potential form of anti-virulence therapy," Toxins, vol. 8, no. 3, article no. 72, 2016.

[4] T. P. Dos Santos, P. Damborg, A. Moodley, and L. Guardabassi, "Systematic review on global epidemiology of methicillinresistant staphylococcus pseudintermedius: Inference of population structure from multilocus sequence typing data," Frontiers in Microbiology, vol. 7, article no. 1599, 2016.

[5] Q. Hu, H. Peng, and X. Rao, "Molecular events for promotion of vancomycin resistance in vancomycin intermediate Staphylococcus aureus," Frontiers in Microbiology, vol. 7, article no. 1601, 2016.

[6] M. Akova, "Epidemiology of antimicrobial resistance in bloodstream infections," Virulence, vol. 7, no. 3, pp. 252-266, 2016.

[7] Z. Golkar, O. Bagasra, and D. Gene Pace, "Bacteriophage therapy: A potential solution for the antibiotic resistance crisis," Journal of Infection in Developing Countries, vol. 8, no. 2, pp. 129136, 2014.

[8] I. M. Gould and A. M. Bal, "New antibiotic agents in the pipeline and how hey can help overcome microbial resistance," Virulence, vol. 4, no. 2, pp. 185-191, 2013.
[9] G. D. Wright, "Something old, something new: Revisiting natural products in Antibiotic drug discovery," Canadian Journal of Microbiology, vol. 60, no. 3, pp. 147-154, 2014.

[10] N. S. Radulović, P. D. Blagojević, Z. Z. Stojanović-Radić, and N. M. Stojanović, "Antimicrobial plant metabolites: structural diversity and mechanism of action," Current Medicinal Chemistry, vol. 20, no. 7, pp. 932-952, 2013.

[11] A. L. Harvey, R. Edrada-Ebel, and R. J. Quinn, "The reemergence of natural products for drug discovery in the genomics era," Nature Reviews Drug Discovery, vol. 14, no. 2, pp. 111-129, 2015.

[12] A. N. Mamun-Or-Rashid, M. K. Sen, M. A. Jamal, and S. Nasrin, "A comprehensive ethno-pharmacological review on Lippia alba," Journal of Biomedical Materials Research, vol. 1, pp. 14-20, 2013.

[13] T. F. Machado, N. A. P. Nogueira, R. D. C. A. Pereira, C. T. de Sousa, and V. C. V. Batista, "The antimicrobial efficacy of Lippia alba essential oil and its interaction with food ingredients," Brazilian Journal of Microbiology, vol. 45, no. 2, pp. 699-705, 2014.

[14] M. B. Figueiredo, G. A. Gomes, J. M. Santangelo et al., "Lethal and sublethal effects of essential oil of Lippia sidoides (Verbenaceae) and monoterpenes on Chagas' disease vector Rhodnius prolixus," Memórias do Instituto Oswaldo Cruz, vol. 112, no. 1, pp. 63-69, 2017.

[15] R. P. Adams, Identification of Essential Oils by Gas Chromatography/Mass Spectrometry, Allured Publishing Corporation, Carol Stream, Ill, USA, 4th edition, 1995.

[16] H. van Den Dool and P. Dec. Kratz, "A generalization of the retention index system including linear temperature programmed gas-liquid partition chromatography," Journal of Chromatography A, vol. 11, pp. 463-471, 1963.

[17] Clinical and Laboratory Standards Institute, "Performance Standards for Antimicrobial Susceptibility Testing; TwentyFifth Informational Supplement," vol. 25, no. 3, 2015.

[18] S. Stepanovic, D. Vukovic, I. Dakic, and B. Savic, "SvabicVlahovic M: a modified microtiter-plate test for quantification of staphylococcal biofilm formation," Journal of Microbiological Methods, vol. 40, no. 2, pp. 175-179, 2000.

[19] T. T. A. Cavalcante, B. A. M. Da Rocha, V. A. Carneiro et al., "Effect of lectins from diocleinae subtribe against oral streptococci," Molecules, vol. 16, no. 5, pp. 3530-3543, 2011.

[20] H. Jannuzzi, J. K. A. Mattos, R. F. Vieira, D. B. Silva, H. R. Bizzo, and L. A. M. Gracindo, "Avaliação agronômica e identificação de quimiotipos de erva cidreira no Distrito Federal," Horticultura Brasileira, vol. 28, no. 4, pp. 412-417, 2010.

[21] L. Espina, R. Pagán, D. López, and D. García-Gonzalo, "Individual constituents from essential oils inhibit biofilm mass production by multi-drug resistant staphylococcus aureus," Molecules, vol. 20, no. 6, pp. 11357-11372, 2015.

[22] F. Gonçalves, F. Barbosa, J. Lima, I. Coutinho, F. Oliveira, and R. Rocha, "Antagonist activity of the essential oil Lippiaalba (Mill," NE Brown (Verbenaceae) on Meloidogyneincognita(Kofoid White) Chitwood. Bras Plantas Med, pp. 18-149, 2016.

[23] A. F. Millezi, D. S. Caixeta, D. F. Rossoni, M. das Graças Cardoso, and R. H. Piccoli, "In vitro antimicrobial properties of plant essential oils thymus vulgaris, cymbopogon citratus and laurus nobilis against five important foodborne pathogens," Ciencia e Tecnologia de Alimentos, vol. 32, no. 1, pp. 167-172, 2012. 
[24] F. J. Sutili, M. A. Cunha, R. E. Ziech et al., "Lippia alba essential oil promotes survival of silver catfish (Rhamdia quelen) infected with Aeromonas sp," Anais da Academia Brasileira de Ciencias, vol. 87, no. 1, pp. 95-100, 2015.

[25] X. Didelot, A. S. Walker, T. E. Peto, D. W. Crook, and D. J. Wilson, "Within-host evolution of bacterial pathogens," Nature Reviews Microbiology, vol. 14, no. 3, pp. 150-162, 2016.

[26] G. H. Dayan, N. Mohamed, I. L. Scully et al., "Staphylococcus aureus: the current state of disease, pathophysiology and strategies for prevention," Expert Review of Vaccines, vol. 15, no. 11, pp. 1373-1392, 2016.

[27] J.-H. Tak and M. B. Isman, "Metabolism of citral, the major constituent of lemongrass oil, in the cabbage looper, Trichoplusia ni, and effects of enzyme inhibitors on toxicity and metabolism," Pesticide Biochemistry and Physiology, vol. 133, pp. 20-25, 2016.

[28] P. Kumar, S. Mishra, A. Malik, and S. Satya, "Housefly (Musca domestica L.) control potential of Cymbopogon citratus Stapf. (Poales: Poaceae) essential oil and monoterpenes (citral and 1,8cineole)," Parasitology Research, vol. 112, no. 1, pp. 69-76, 2013.

[29] S. Kpoviessi, J. Bero, P. Agbani et al., "Chemical composition, cytotoxicity and in vitro antitrypanosomal and antiplasmodial activity of the essential oils of four Cymbopogon species from Benin," Journal of Ethnopharmacology, vol. 151, no. 1, pp. 652659, 2014.

[30] D. P. De Sousa, F. F. De Farias Nóbrega, and R. N. De Almeida, "Influence of the chirality of (R)-(-)- and (S)-(+)-carvone in the central nervous system: a comparative study," Chirality, vol. 19, no. 4, pp. 264-268, 2007.

[31] M. Znini, M. Bouklah, L. Majidi et al., "Chemical composition and inhibitory effect of Mentha spicata essential oil on the corrosion of steel in molar hydrochloric acid," International Journal of Electrochemical Science, vol. 6, no. 3, pp. 691-704, 2011.

[32] K. K. Aggarwal, S. P. S. Khanuja, A. Ahmad, T. R. S. Kumar, V. K. Gupta, and S. Kumar, "Antimicrobial activity profiles of the two enantiomers of limonene and carvone isolated from the oils of Mentha spicata and Anethum sowa," Flavour and Fragrance Journal, vol. 17, no. 1, pp. 59-63, 2002. 

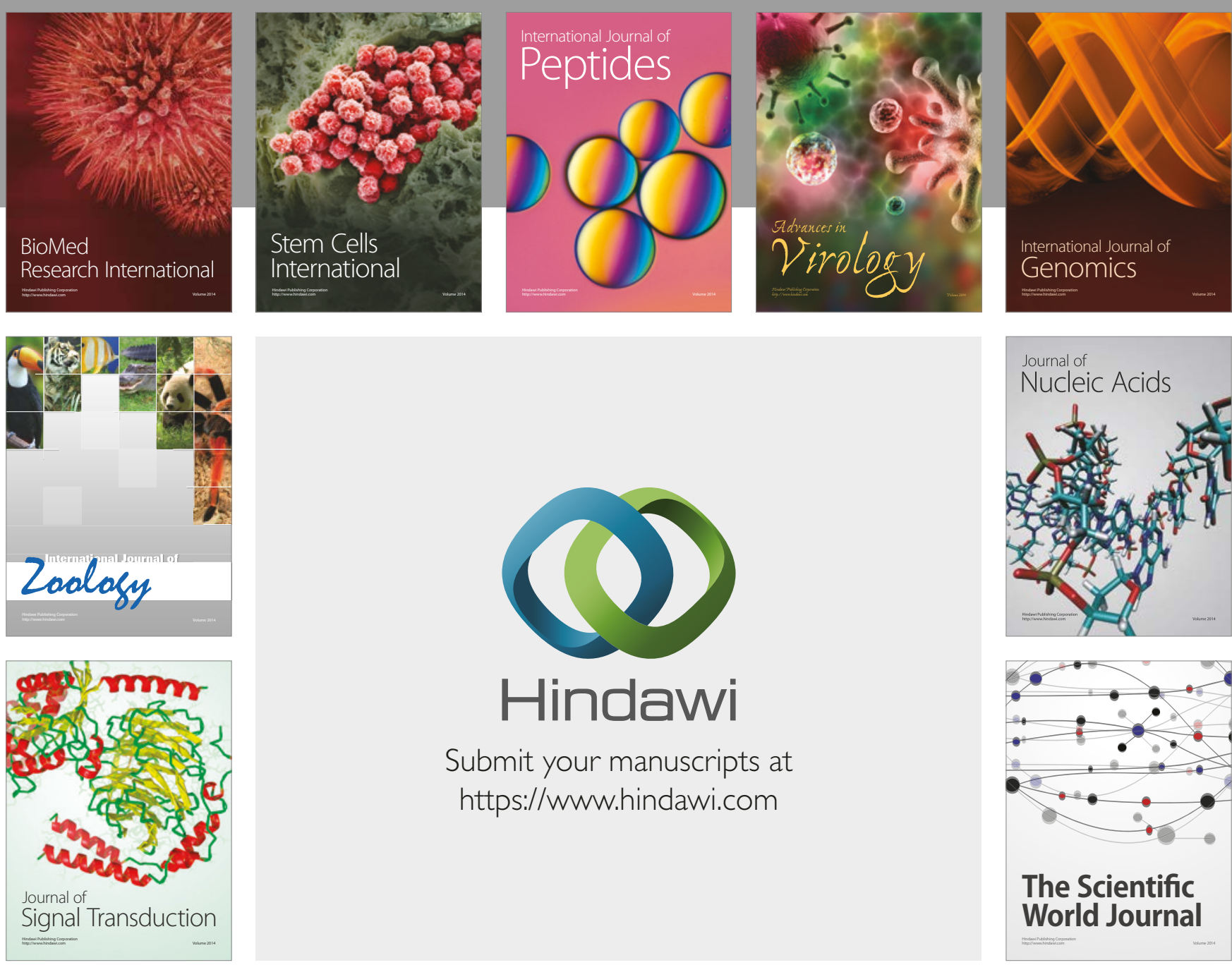

Submit your manuscripts at

https://www.hindawi.com
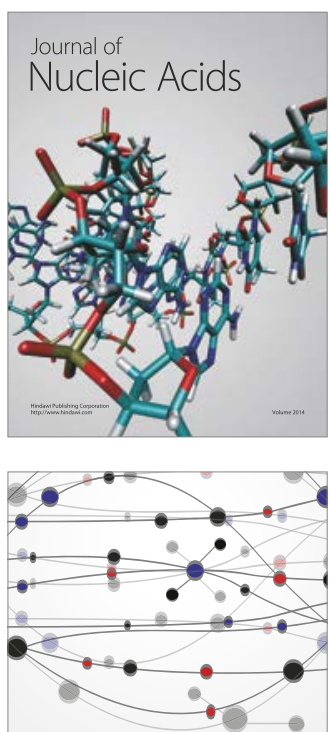

The Scientific World Journal

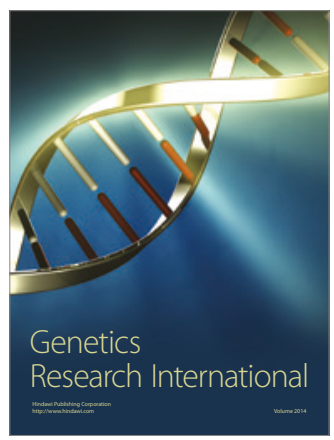

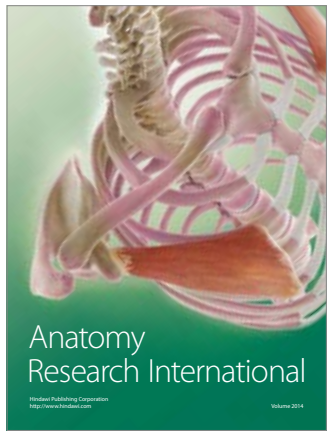

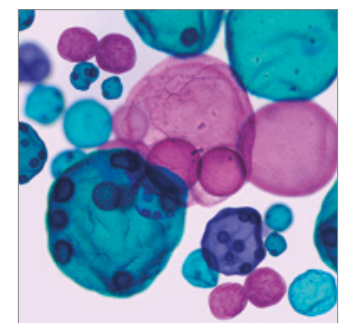

International Journal of Microbiology
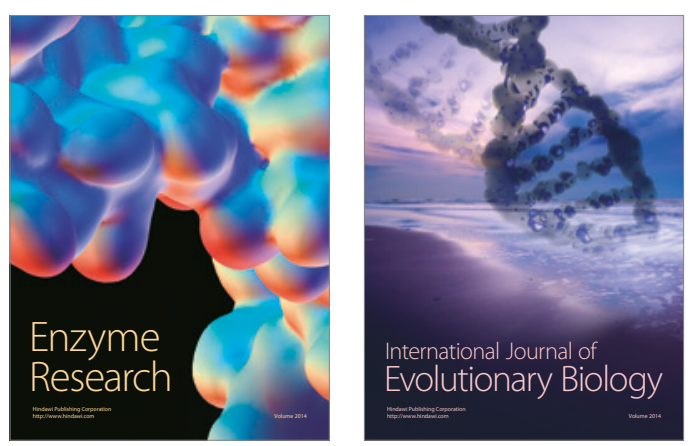
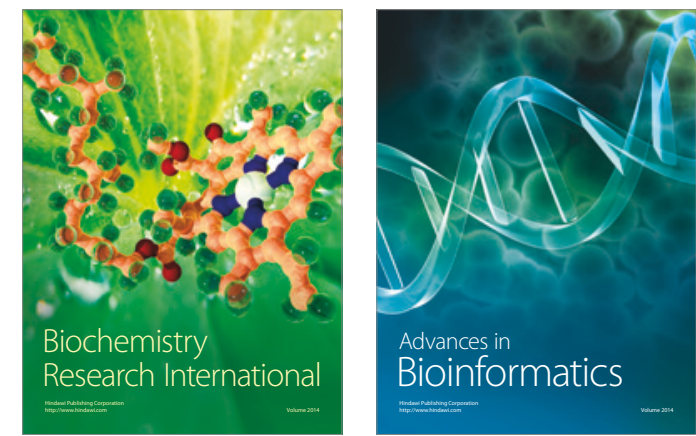

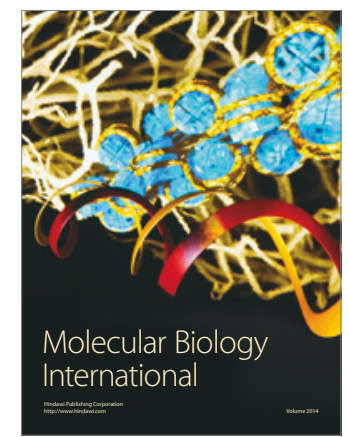

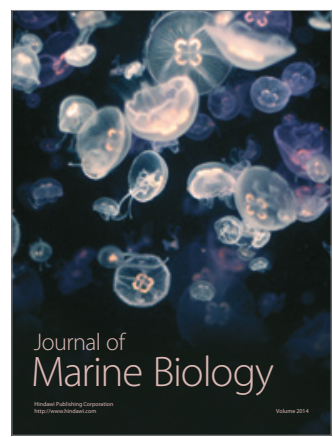

